INDEPENDENT JOURNAL OF MANAGEMENT \& PRODUCTION (IJM\&P)

http://www.ijmp.jor.br

v. 11, n. 4, July - August 2020

ISSN: 2236-269X

DOI: 10.14807/ijmp.v11i4.1136

\title{
A BIBLIOGRAPHICAL ANALYSIS IN THE LITERATURE OF VALUE CO-CREATION IN PRIVATE HIGHER EDUCATION BETWEEN THE YEARS 2006 TO 2016
}

\author{
Maicon da Silva \\ Universidade de Santa Cruz do Sul, Brazil \\ E-mail:maicon213@bol.com.br \\ Luis Carlos Alves da Silva \\ Universidade de Santa Cruz do Sul, Brazil \\ E-mail: luiscarlosalves0207@gmail.com \\ Flávio Régio Brambilla \\ Universidade de Santa Cruz do Sul, Brazil \\ E-mail: flaviobr@unisc.br
}

Submission: $10 / 5 / 2019$

Accept: 10/22/2019

\section{ABSTRACT}

The present research aims to present a bibliographical analysis of scientific publications on the theme "value co-creation in private higher education", carried out from 2006 to 2016. Methodologically, this article was carried out through a bibliographical survey, with the objective of selecting the publications made in scientific journals in the pre-stipulated period. Form 54 publications were selected. It was observed that in the year 2016 there were the highest number of publications (10), already years of 2006, 2007 and 2013 were the ones with the lowest number of publications (2). Also, it was identified that the authors that obtained the most prominence in the research were Robert F. Lusch and Stephen L. Vargo, where they obtained (5) publications each. In relation to the most published journals on the subject were Journal of Business Research and Journal of Service Management, with (3) publications each. In this context, it was possible to note that the words that were the most successful in high repetition were: value co-creation, logic dominant of service, value, service. The relevance of this research comes from the moment that value co-creation is seen as an important tool for marketing administration allowing for constant 
DOI: 10.14807/ijmp.v11i4.1136

improvements through the exchange of experiences between teachers and students in the classroom environment. Thus, in private higher education, student satisfaction and value creation are the result of individual or joint actions (institution, teacher and student).

Keywords: Value Co-creation, Private Higher Education, Classroom.

\section{INTRODUCTION}

The market goes through transformations that form a dynamic and complex context for organizations that are inserted. In this context are the companies that have access to information with greater agility to convert such information on benefits, capturing the essence of marketing and surpassing the expectations of its customers (MATIAS et al., 2015).

When part of the presupposition that the organizational environment goes through a time of great complexity and dynamism, organizations need to find ways to generate competitive advantage in your market, creating a determining factor between organizational success or failure as well as a factor of organizational competitiveness.

The competitive advantage can be conceptualized as the biggest difference between the production costs and the disposal of the client to pay for the product (GHEMAWAT, 2007). In higher education, despite the difficulty of dealing with a relationship between consumer and product on the basis of the activity substantivities the discussion between the earned value between students and their perception in the process of teaching and learning becomes a challenge for institutions of higher education.

For a better understanding, it is necessary to understand what the market needs to offer services with a higher value from competitors to meet these demands, that is, "the idea of greater interactivity between the institutions, students and the experiences generated at the meeting may represent consumer value (PAYNE; STORBACKA; FROW, 2008, p. 243)”.

Along the same lines, in recent years the market environment has been characterized by striking changes, marked by a scenario of technological development, offer of similar products between competitors and, consequently, greater competition, determining to the companies the need to explore new approaches to the creation of value (RAMASWAMY, 2009a).

Thus, during the purchase or delivery of goods and / or services, the parties may interact, and in this interaction, according to Grönroos (2011), in this path that opportunities for value co-creation occur or arise. Value co-creation, as defined by Grönroos and Ravald (2011), is a process of providing resources for customer use that must transform them into value. In this 
DOI: 10.14807/ijmp.v11i4.1136

sense, the process of value co-creation is a topic that has been discussed in the last decade, and also in academia, mainly by the few researches that demonstrate in practice how and when consumers interact with organizations in order to value co-creation (WOODRUFF; FLINT, 2006; PAYNE; STORBACKA; FROW, 2007).

Co-creation, or co-production, is nothing more than the occurrence of active consumer participation in the service, generating added value through customization, and culminating in satisfaction (PRAHALAD; RAMASWAMY, 2004a). For Troccoli (2010), the essence of cocreation in services is the search for a better composition of consumer value, meeting their individual interests.

Given this question and the importance of value co-creation for organizations and academia, the literature review aims to analyze publications related to co-creation of value in private higher education, focusing on the last decade, that is, between 2006 and 2016, from the database available on the Capes Portal, and the theoretical contribution that these publications bring to a better understanding of the proposed theme.

Following this context, it is possible to commit actions that encourage value co-creation between teachers and students in higher education private, on aegis of quality in higher education. Under is perspective, through the elaboration of a descriptive study, which has as general objective: to present the objections about the value co-creation in private higher education through a literature review of publications of the last decade comprehend the years 2006 to 2016.

In this sense, the importance of this article in the administration of marketing, relates to the fact that the research aligns the different contexts related there is value co-creation, but specifically in the higher education sector. Therefore, when an organization decides to cocreate means that the same is offering to invite your customer to dig deep in the process of creating, in a highly collaborative. This is the same: the consumer in this case, the student shall have the decisive role in time to create a product and/or service new or even bring different ideas that help the teaching institution to improve their processes.

It will, in this article, list the objections about studies on the co-creation of value in private higher education through a literature review of publications. In this context, the article was structured into five sections, including this introduction. In section 2, it presents the theoretical synthesis about the theme and its contextualization's; followed by section 3 which 
DOI: 10.14807/ijmp.v11i4.1136

presents the methodological aspects. Presentation of the results is performed in section 4, and in section 5 are presented the final considerations.

\section{THEORETICAL FOUNDATION}

\subsection{Value Co-creation}

The theme of co-creation of value is still recent, and discussions about it gain strength as it evolves to the establishment of a networked society and customer behavior is similar to that described by Prahalad and Ramaswamy (2004), in which the active participation of the consumer becomes a form of differentiation against competitors.

For Payne, Storbacka and Frow (2008, p. 84) "The customer is always a co-creator of value". The authors believe that there is no value until an offer is used, and the experience and perception of the customer therein are essential for the determination of value. Holbrook (2002) defines value for the consumer as an "interactive experience of relativistic experience". In other words, what defines what is valuable to one client is the experience derived from the interaction.

Organizations that wish to compete in this market, which presents a number of challenges need to change their structures for value co-creation, making your information transparent and accessible to all its employees, transforming interactions with its chain of customers of mere financial transactions, for a significant moment of dialog and exchange of experiences.

One of the central characteristics in the process of co-creation of value refers to the high quality of the interactive processes. These "allow the individual consumer co-create unique experiences with the firm", a way to generate value and competitive advantage to the company (PRAHALAD; RAMASWAMY, 2004, p. 7).

The value is viable through a relationship of creative duality exerted in synergetic initiatives involving business and consumer. Emphasize Slater and Olson (2000), that the relationships between vendors and customers/ consumers favor the company known latent needs of the consumer. This ratio is favorable to develop bids before that competitors do, providing higher value-added service. A co-disinvolvement between company and consumer is fundamental because the "Value is co-create with the consumer" (VARGO; LUSCH, 2004, p. 4). 


\section{INDEPENDENT JOURNAL OF MANAGEMENT \& PRODUCTION (IJM\&P) \\ http://www.ijmp.jor.br \\ v. 11, n. 4, July - August 2020}

ISSN : 2236-269X

DOI: 10.14807/ijmp.v11i4.1136

In this sense, the value is derived from co-creation to the consumer, and for this type of value creation, companies not only need to expand customer bases, but refine that feature (SRIVASTAVA, SHERVANI; FAHEY, 1998). Refers to develop and provide a superior service, which is intangible asset, to be constructed and protected (SLATER; OLSON, 2000). The future of the market, for companies that wish to obtain success, involves understanding what is needed co-creation, having in view the development of unique experiences co-creation with consumers" (PRAHALAD; RAMASWAMY, 2004, p. 12).

For this reason, the value co-creation is a subject of growing importance in marketing literature, and gained momentum from the publications of Prahalad and Ramaswamy (2004a; 2004b) and Vargo and Lusch (2004). This logic, the value would not be defined within the company and delivered to the consumer, but co-creation with him from the engagement between customer and company (VARGO; LUSCH, 2004).

Thus, the company does not deliver value, but rather the delivery service and proposes the potential value of the same, which is co-creation with the consumer (WITELL et al.; KRISTENSSON; GUSTAFSSON; LÖFGREN, 2011). Therefore, studies on co-creation are relevant, because it helps to understand how customers will be active elements in the relationship, not only a target for the company (VARGO; LUSCH, 2004; VARGO; LUSCH, 2006; VARGO; LUSCH, 2011). In addition, also reveal how the co can impact on understanding of satisfaction and consumer confidence (MEUTER; OSTROM; ROUNDTREE, BITNER, 2000; ROMERO; MOLINA, 2011), as well as understand the goals of clients and companies (RAY et al., 2012) for the construction of lasting relationships between them (WITELL et al., 2011).

\subsection{Value Co-creation in Private Higher Education}

The co-creation in education, especially higher, implies the involvement of students in the elaboration of the results (QIAN, 2006). In the classroom is possible co-creation through activities such as remedy doubts, both discorded personal touches, such as discussions and questions, by the interaction in the teaching-learning environment. Out activity is also important in the co-creation educational. Kotzé and Plessis (2003) highlight the variety of means to co-creation in class, being the value resulting from the concept of quality (ALVES; RAPOSO, 2007). 
DOI: 10.14807/ijmp.v11i4.1136

On the other hand, co-creation can be defined as active consumer participation generating higher performance and value in the service, and later satisfaction (PRAHALAD; RAMASWAMY, 2004a). In this sense, Brambilla (2010, p. 16), quotes the following:

[...] An example of co-creation, or co-production (similar terms) is the educational setting, where students with different expectations are met by teachers and, even in a group or class, it is possible to meet the different demands. Professor and University interests, as well as the community, complete this understanding of co-creation as a broader term that incorporates more than simple interaction or service delivery [...]

In classroom relationships there is participation and interaction, concepts that form what is meant by co-creation. Vargo (2008, p. 212) mentions that "value co-creation always requires involvement”. Co-creation through an exchange relationship proves to be a source for the generation of educational values in the service encounter of private higher education (CHUNG, MCLARNEY, 2000; SILVA, 2003; DONG; EVANS; ZOU, 2008). For example, in Chung and McLarney (2000), through experiences conducted with students, it was found that the classroom in order to experience learning, through interaction, provides results superior to those of passive teaching, despite the difficulties to learn the conduct of the process. The notion of living the classroom is for the authors a way to generate higher learning outcomes, greater value generation. Student participation is a basic criterion for learning, in interaction with the teacher (FASSINGER, 1995; KOTZÉ; PLESSIS, 2003; ATHANASIOU, 2007; GRANTZ; KOENING; HARICH, 2009).

Given the importance of co-creation for the generation of value for students, it is important to emphasize the complexity of the provision of educational services, since in this case the student (client) responds for the result of the process of service provision, ie the academic performance becomes an important part of the Faculty, Course and Student relationship (MATIAS et al., 2015). Still, in this scenario, educational services and, specifically, private Higher Education Institutions (HEIs) have sought to differentiate themselves through the development of more effective, high quality teaching methods and service processes (RIBEIRO, 1999; MEYER JÚNIOR; MURPHY, 2003).

According to Hofstatter (2010), private higher education institutions are in a highly competitive market, they need to be prepared, both to attract more students and to retain existing students, so that they do not migrate to competition. Therefore, the quality of teaching, the value proposition for the students, is necessary. Abrantes, Seabra and Lajes (2007), Duke (2002), Sierra (2009) and Clayson (2009) reinforce in their studies the importance of higher education institutions to be concerned with student learning and the aspects involved in this process, such as teacher-student interaction and the performance evaluation process. 


\section{INDEPENDENT JOURNAL OF MANAGEMENT \& PRODUCTION (IJM\&P)}

http://www.ijmp.jor.br

v. 11, n. 4, July - August 2020

ISSN : 2236-269X

DOI: 10.14807/ijmp.v11i4.1136

In this sense, in the ambience of higher education, especially in stricto sensu courses, students may even co-create in the construction of the contents of interest. This idea is compatible with that of Vargo and Morgan (2005), that the service is a specialization activity, involving skills and abilities, and knowledge. Bendapudi and Leone (2003) point out that, in these cases, consumers assume an active role in the creation of the service. It is known that, in the case of services, including the Private Higher Education service, "the company is the main brand” (D'AAVILA; DAMACENA; GARRIDO, 2008, p. 5). Also, that the organizational image is an important indicator for the appreciation of both the institution and the service it develops, which culminates in student satisfaction (ALVES; RAPOSO, 2007). Similar results are found in Bendapudi and Leone (2001, p. 107), when it is referred to as necessary for success that the "company must always build a "quality image proactively, continuously and consistently”.

Interesting is the perception that one must be more than a consumer of educational services, but an actor engaged in learning. Young (2005, p. 36) says that active learning "increases students' perception of their perceived autonomy," and thus intrinsic motivation favors learning.

Brambilla and Damacena (2012) point out that student participation in the classroom is made up of three variables, which are, respectively, the class profile (which highlights how participation is performed and how to learn, according to student profiles, number of students in the class, etc.); the students (it deals with the individual aspects, but global, and it involves the gender, age range, the absorption and comprehension capacities of the one proposed by the course); and teacher (includes interaction with students, teacher qualification and didactics, and how communication develops between teacher and students). An additional variable not mentioned by the author may be included, which concerns the relationship between Institution (staff) and students.

\section{METHODOLOGY}

This article was conducted through a bibliographical analysis with the purpose of analyzing the articles published exclusively on the theme of Co-creation of Value in Private Higher Education from articles available in the Portal Capes databases from 2006 to 2016. For Oliveira et al (2013), the use of bibliometric research is a primary resource for the transmission of scientific production and its purpose is achieved by applying a technique capable of measuring the influence of researchers. or periodicals, allowing to outline the profile and 


\section{INDEPENDENT JOURNAL OF MANAGEMENT \& PRODUCTION (IJM\&P) \\ http://www.ijmp.jor.br \\ v. 11, n. 4, July - August 2020}

ISSN : 2236-269X

DOI: 10.14807/ijmp.v11i4.1136

trends, as well as highlighting thematic areas. Of similar opinion is Moraes (2013), who claims that bibliometric research is an analysis for scientific productions, which allows the support for the production of new works.

In this sense, the methodology is the science of methods, it is characterized by being a totally rigorous explanation of all action taken during the research. Thus, in this article, it was conducted through qualitative exploratory research, seeking to obtain knowledge on the subject that is the subject of much debate today due to changes in higher education in Brazil.

Due to the specificity of the research, a qualitative depth analysis was sought in conjunction with the bibliographic analysis with reflective perspective without pretending to generalize the findings. For, according to Oliveira (1998, p. 116), "the qualitative method is not intended to number or measure homogeneous units or categories”. According to the same author, this type of approach makes it easy to describe about a certain hypothesis or problem.

\subsection{Data collection steps}

The research in question was carried out in 7 stages (Chart 1), starting with the search for the theme subjects in the Capes Portal. The words used were in the English language, but the search was not limited to articles in the English language only. Regarding the journals, for further research there were no limitations. As a way to refine and centralize the search on the desired theme, we used quotation marks at the beginning and end of the words ("co-creation of value”, "service dominant logic" "co-creation of value in private higher education") and the time interval of publications from the year 2006 to 2016, and the research was conducted on

October 08, 2017.

Table 1: Research Steps

\begin{tabular}{|c|c|}
\hline Search Stpes & Description \\
\hline Steps 1 & $\begin{array}{l}\text { On October 8, 2017, the search for the subject was performed: "value co-creation", } \\
\text { "service dominant logic", "value co-creation in private higher education". }\end{array}$ \\
\hline Steps 2 & The search was refined only for the interval between 2006 and 2016. \\
\hline Steps 3 & $\begin{array}{l}\text { One more refinement by selecting only the topics: value co-creation, service dominant } \\
\text { logic, value co-creation in private higher education. }\end{array}$ \\
\hline Steps 4 & Reading of abstracts and separation of articles to a folder created on the computer. \\
\hline Steps 5 & Microsoft Excel tabulation: authors, keywords, journal and year of publication. \\
\hline Steps 6 & $\begin{array}{l}\text { Statistical analysis in IBM SPSS } 20 \AA \text { from the Authors, Year of Publication, and } \\
\text { Periodicals column. }\end{array}$ \\
\hline Steps 7 & Creating a Word Cloud in Word Cloud Creator. \\
\hline
\end{tabular}
Source: Prepared by the authors based on research.

Thus, based on the steps proposed in Table 1, a bibliographic analysis of the publications of the last decade was performed, covering the years 2006 to 2016 of this study.

\section{PRESENTATION AND DISCUSSION OF RESULTS}




\section{INDEPENDENT JOURNAL OF MANAGEMENT \& PRODUCTION (IJM\&P)}

http://www.ijmp.jor.br

v. 11, n. 4, July - August 2020

ISSN : 2236-269X

DOI: 10.14807/ijmp.v11i4.1136

The main purpose of data analysis is to enable the researcher to draw conclusions from the collected data. According to Aaker, Kumar and Day (2001), this analysis comprises a set of techniques and methods that can be employed to obtain information and discoveries from the collected data. Malhotra (2001) comments that the data preparation phase requires a lot of attention and care, in order to obtain the statistical results with quality. Unless due attention is given at this stage, statistical results can be compromised leading to biased results and misinterpretations.

Regarding the results obtained in the research, it is evident in this chapter analysis of data from the 54 articles, which were obtained through the methodology applied in the search for those articles. Regarding the main authors who published between 2006 and 2016 related to the subject of this bibliometric research, they were highlighted in Table 2.

Table 2: Main authors between 2006 and 2016

\begin{tabular}{|l|c|}
\hline \multicolumn{1}{|c|}{ Autor } & Frequência \\
\hline Robert F. Lusch & 5 \\
Stephen L. Vargo & 5 \\
Flávio Régio Brambilla & 2 \\
Lia Krucken & 2 \\
Adrian Payne & 1 \\
Amanda Saraiva Zmoginski & 1 \\
Ana Paula Matias & 1 \\
Antonio Sergio da Silva & 1 \\
Bartos Bernardes & 1 \\
Benny Kramer Costa & 1 \\
Bianca Zappardi Barbara & 1 \\
Christian Grönroos & 1 \\
Clara Isabel Koetz & 1 \\
Claudio Damacena & 1 \\
Daniela Camarinha & 1 \\
Eduardo Raupp de Vargas & 1 \\
Elenise Angélica Martins da Rocha & 1 \\
Fernando de Oliveira Santini & 1 \\
\hline
\end{tabular}

Source: Bibliographic analysis data

Chart 2, 18 authors are highlighted, through the frequency analysis of the SPSS 20®, it was identified that the authors with the largest number of publications were Robert F. Lusch and Stephen L. Vargo, with five works each published on the theme of this topic. search. Other authors had two publications each within the defined time frame. It has been noted that a large number of authors have published only once on this topic.

Thus Robert F. Lusch graduated with his PhD from the University of WisconsinMadison in 1975 and began his academic career at the University of Oklahoma. After working at the University of Oklahoma for 26 years, including 5 years as dean of his business school (1987-1992), Lusch became dean of the MJ Neeley School of Business at Christian University 
DOI: 10.14807/ijmp.v11i4.1136

of Texas in 2000. At that time, Lusch has written 14 books and published 150 articles in various professional journals. Lusch's research was published in the Journal of Marketing, Journal of Consumer Research, Journal of Marketing Research, Marketing Science, Journal of Retailing, Accounting, Organizations and Society, Sloan Management. Review, Organizational Dynamics, IEEE Intelligent Systems, Journal of Operations Management, IBM Systems Journal and Behavioral Science.

Already, Stephen L. Vargo, Ph.D is a Distinguished Professor Shidler and Professor of Marketing at Hawai'i University in Manoa. He has a master's degree in social psychology and a Ph.D. in marketing. He has held visiting positions at the University of Maryland, College Park, the University of California, Riverside and the University of Auckland. Prior to joining the academic field, he had a career in entrepreneurial business and was a consultant to several major national, regional and local corporations and government agencies.

Professor Vargo's main research areas are marketing theory and thinking, dominant service logic (marketing), and consumer evaluative reference scales. He has published articles in the Journal of Marketing, the Journal of the Academy of Marketing Science, the Journal of Service Research, the Journal of Retailing, the Journal of Macromarketing, and other marketing publications and books, including The Service Dominant Logic. Marketing: Dialogue, Debate and Directions, which he co-edited.

Regarding the journals, as shown in Table 3, the journal with the largest number of publications related to the theme of this research was the Journal of Business Research and Journal of Service Management with three publications each, at the time determined for the research. In this context, the European Journal of Marketing; J. of the Academy of Marketing; Sage Journals, produced two publications each. Table 3 presents only the journals that have presented at least two publications in the last decade.

Table 3: Journals with publications related to the theme

\begin{tabular}{|c|c|}
\hline Author & Frequency \\
\hline Journal of Business Research & 3 \\
\hline Journal of Service Management & 3 \\
\hline Europan Journal of Marketing & 2 \\
\hline J. of the Academy of Marketing & 2 \\
\hline Sage Journals & 2 \\
\hline
\end{tabular}

In this sense, the Journal of Business Research applies theory developed from business research to real business situations. Recognizing the intricate relationships between the various 
areas of business activity, JBR examines a wide variety of business decisions, processes and activities within the real business context.

Theoretical and empirical advances in buyer behavior, finance, organizational theory and behavior, marketing, risk and insurance, and international business are regularly assessed. Published for executives, researchers and academics, the Journal of Business Research assists the application of empirical research in practical situations and theoretical insights into the reality of the business world.

In contrast, the Journal of Service Management focuses on service management research. The journal publishes articles that show a unique and significant contribution to the service literature and provides a means of communication for those working in the field of service management, regardless of discipline, functional area, sector or nationality. The journal publishes double-blind revised articles that focus on service literature / theory and its applications in practice.

Following the research, there was the classification of the years of publications, as shown in Graph 1. It is observed that in 2016 there was the largest number of publications.

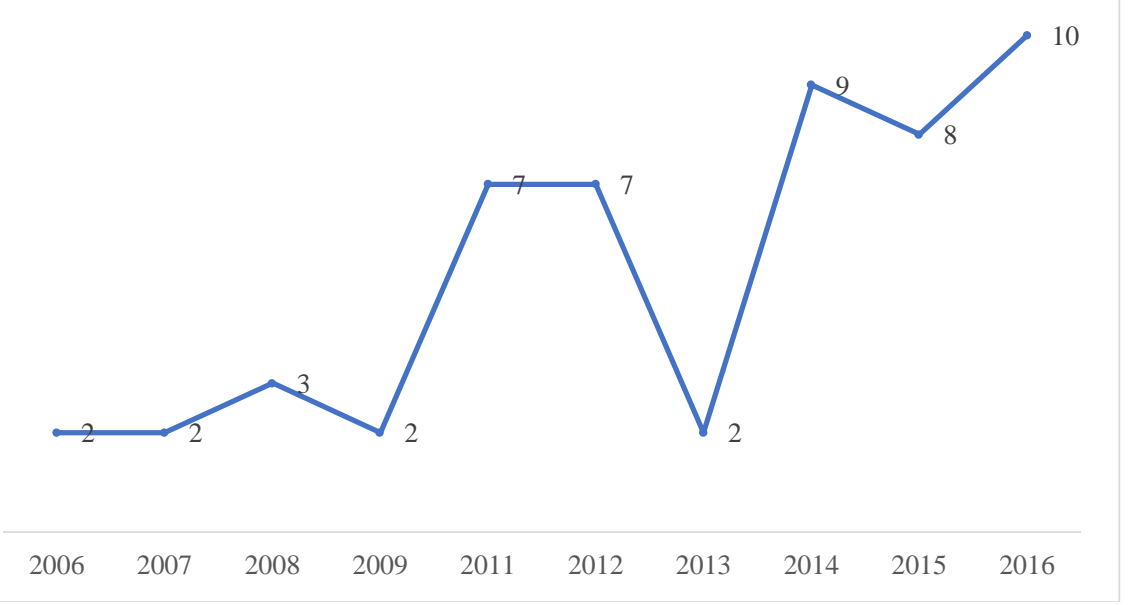

Graph 1: Publications by year

Source: Bibliographic analysis data

Second is 2014 with nine publications, 2015 with eight publications. In 2011 and 2012 respectively seven publications. Already in the year 2008 with three publications. In 2006, 2007, 2009 and 2013 there were two publications.

Another issue analyzed in the articles was the keywords, which were elaborated with the help of the free online application called Jason Davies Word Cloud ${ }^{\circledR}$, a word cloud which is represented by Figure 1 . 


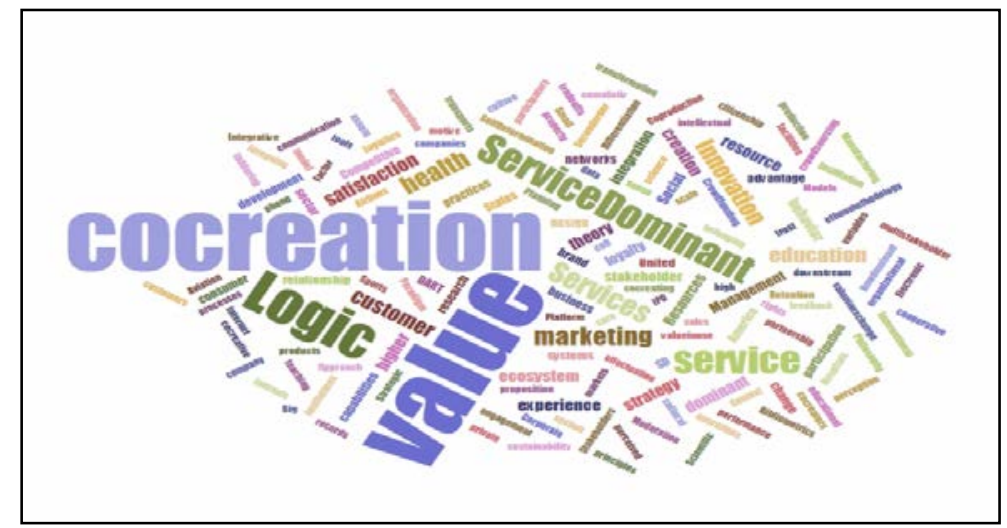

Figure 1: Word Cloud

Source: Bibliographic analysis data

It can be easily noticed that the words that most highlighted the high repetition were: co-creation, service dominant logic, value.

Value co-creation has been studied in administration over the last few years. During this period, the active participation of clients and / or consumers in the value co-creation process in organizations has been considered (RIBEIRO; TAVERES; COSTA, 2016). In this context, co-creation as an innovative and value-adding factor has a great ability to please the customer.

In this new strategy, companies not only interact with customers to deliver personalized services, but also develop and strengthen operational capabilities. Because the customer participates in the creation of the product they want to acquire, and the chances that this product will generate satisfaction and loyalty behaviors are maximized (BERNARDES; LUCIAN, 2015).

Thus, to truly transform customer value into competitive advantage, it is first necessary to understand how customers form their perceptions of value and to develop ways to measure them. Thus, in order for the value increase to occur on the basis of the customer's relationship with the company, it is essential to know what the customers value, that is, what is value to them (CAMARINHA; COSTA; VIEIRA, 2013).

Already, the dominant logic of service calls for a shift of focus from essentially tangible goods to intangible benefits. As an example, skills, knowledge and processes, rooted within the service. One of the attractions of this focus lies in reconciling product and service attributes as complementary, without excluding one of the categories (product + service), (BRAMBILLA; DAMACENA, 2011). 


\section{INDEPENDENT JOURNAL OF MANAGEMENT \& PRODUCTION (IJM\&P)}

http://www.ijmp.jor.br

v. 11, n. 4, July - August 2020

ISSN : 2236-269X

DOI: 10.14807/ijmp.v11i4.1136

For the authors, it is understood in the "Service Dominant Logic" (SDL) that the service configures more than product support. Of SDL's most relevant Foundational Assumptions (PFs), it stands out for the consumer in the role of "value co-creator", that is, the service encounter (which is the co-creation locus), represents series of interactions and transactions in relationships. between company and customer.

Brambilla and Damacena (2011) state that the idea of greater interactivity between company and customer, and the experiences generated at the meeting, can represent value to the consumer. The relationship between product and service, in the dominant logic of service marketing, is evidenced by mentioning that every product "is an application used in service provision." In other words, the authors point out that it is not the physical characteristics of the products, but the benefits they generate (service) that ultimately characterize what is really relevant to the consumer.

On the other hand, the Service-Based Logic-based view is challenging economic principles and this new perspective is gaining notoriety in the literature, especially in the Marketing area, where this view proposes a new framework in which services represent the forefront of information systems. economic exchanges, opposing the commodity-based view (MORAES; COSTA, 2012).

For a better understanding, the authors point out that Management Theory and Business Practices in classical economics are centered on a dominant commodity logic, but that this logic may not be the most consistent with the fundamental role of services in a modern economy.

In other words, according to the LDS, a service or service provides an application of knowledge and skills for the benefit between the agents involved (consumer and business), thus providing value co-creation. In addition, LDS places the customer at the center, so that the customer is always a co-creator and, on the other hand, the company does not offer value but provides value.

Given the above, the concept of value has been widely discussed as a critical variable. The most recent research shows a clear tendency to understand the customer value produced not by the producing company, but by the consumer when using the product and interacting with co-creation suppliers with them. Previous research has cited that consumers value the value of products based on what they receive and what is sacrificed. The notion that only the consumer can value the value of goods and services had already been expressed by (DIETRICH; BRAZIL; FRIO, 2013). 
DOI: 10.14807/ijmp.v11i4.1136

For Saraceni (2015), the concept of value has been investigated and conceptualized in different areas of knowledge such as economics, sociology, anthropology, psychology and social psychology, having a very subjective definition when viewed from the point of view of management. Value typologies are as old as the initial effort to know these guiding principles.

Still, the concept of value in marketing receives influences from various areas of knowledge. In the context of exchange, value was initially the focus of study of economics, as Richins (1994, p. 504) explains: “economic literature has given rise to value within the context of exchange; The value of a product to a consumer is represented by the price it expects to pay and stems from the utility or satisfaction that the product provides”.

In marketing literature, however, value study takes a slightly different perspective, since purely economic considerations are not sufficient to understand what drives an individual to purchase or use a product; “There are many reasons to believe that economic value cannot fully capture the true value of many of the objectives possessed by consumers” (RICHINS, 1994, p. 504). From a marketing perspective, value confronts perceptions and choices, not only being linked to the economic aspect of purchasing a product.

The marketing approach, Oliveira and Ikeda (2005), points out that value confronts perceptions and choices, not only being linked to the economic aspect of purchasing a product. Value in the marketing area is also influenced by Psychology and Sociology when it refers to the behavioral aspects of the audiences involved. The concept of value in this context may have the connotation of personal or individual values. Within this approach, the authors state that values are end-states of life and consist of the goals and objectives for which one lives.

\section{FINAL CONSIDERATIONS}

The proposed study aimed to make a bibliographical analysis on the scientific articles dealing with the theme value co-creation in the last decade (2006 to 2016) in search of differentiation and competitiveness. Regarding the theoretical contribution, it can be seen that the studies by Prahalad and Ramaswany (2004); Nambisam (2002); Ciccantelli and Magison (1993), suggest that companies need to co-create value to gain advantage over their competitors.

In private higher education this scenario is no different, as students expect course managers to be able to offer differentials that motivate them to stay in a particular institution over the other options available in the market (MATIAS et al., 2015). Brambilla and Damacena (2012) sought to identify the point of private education in which the student as a consumer is 


\section{INDEPENDENT JOURNAL OF MANAGEMENT \& PRODUCTION (IJM\&P) \\ http://www.ijmp.jor.br \\ v. 11, n. 4, July - August 2020}

ISSN : 2236-269X

DOI: 10.14807/ijmp.v11i4.1136

directed to a reality closer to the ideal for learning, where the student becomes a co-creator in the educational locus.

On the other hand, in the dynamic context of the classroom teachers should have the ability to conduct the process and master the tools, so suggest the most appropriate to the scenario in question, the skills needed to facilitate this process, understanding that the role is to approach the content systematically and objectively, seeking to strengthen the development of strategic thinking and promote a space for exchange of experiences in the process of teaching learning (SANTIAGO; COUTINHO, 2013).

In this context, the findings in this article aimed to make a bibliographical analysis of the publications of the last decade covering the period from 2006 to 2016, and this research was carried out in seven stages, starting with the search for subjects in the Capes Portal. Also, it was evidenced in this article the analysis from 54 articles that were obtained through the search carried out in the referred Portal.

It was also found that Robert F. Lusch and Stephen L. Vargo were the authors with the largest number of publications in this bibliographic survey of publications of the last decade (2006 to 2016), which began the studies on value co-creation. Regarding the journals, it was found that the Journal of Business Research and Journal of Service Management were cited as the journal of major publications related to the theme of this research. Thus, in the present study, 2016 was the year with the highest number of publications. Given the above, it was possible to notice that the words that had more repetition in the word cloud were: co-creation, service dominant logic, value.

The study concludes with a reflection on co-creation as a mechanism of social value (EDVARDSSON; TRONVOLL; GRUBER, 2011). The human being "does not perform his work as an isolated being, but always as a member of a group united by the cooperation necessary to perform the work, or by the association of friendships” (HOMANS, 1977, p. 41). As the passage above states, interaction is an important social tool for learning (VARGO, 2008).

Like all qualitative deep research, this research does not aim to reach hypothesis tests nor affirm positively findings. The analysis focused on the publications highlighted in this bibliographical analysis and on the reflection on the subject that is a recurrent subject in educational organizations. 
DOI: 10.14807/ijmp.v11i4.1136

With the possibility of research, co-creation stands out as a possibility of multidimensional organizational development (FONTOURA; WITTMANN, 2016) on the path for new forms of alternative organizational dynamics in organizational studies with interactive view through an epistemological view not only linked to the growth view. and in the prevailing classical school of administration in the applied social sciences. Like all in-depth qualitative research, this research is not intended to reach hypothesis tests or positively affirm findings. The analysis focused on the publications highlighted in this bibliographical analysis and the reflection on the subject. which is a subject that is currently recurring in educational organizations.

\section{REFERENCES}

AAKER, A. D.; KUMAR, V; DAY, S. G. (2001) Pesquisa de Marketing. São Paulo: Atlas.

ABRANTES, J. L.; SEABRA, C.; LAGES, L. F. (2007) Pedagogical affect, student interset, and learning performance. Journal of Business Research. v. 60, p. 960-964.

ALVES, H.; RAPOSO, M. (2007) Conceptual Model of Student Satisfaction in Higher Education. Total Quality Management, v. 18, n. 5, p. 571-588.

ATHANASIOU, A. (2007) Developing Learner Autonomy through Collaborative Learning in a Higher Education Context. Journal of Business and Society, v. 20, n. 1, p. 115-129.

BENDAPUDI, N.; LEONE, R. P. (2003) Psychological Implications of Customer Participation in Co-Production. Journal of Marketing, v. 67, p. 14-28.

BENDAPUDI, N.; LEONE, R. P. (2001) How to Lose your Star Performer without Losing Customers. Too. Harvard Business Review, p. 104-112.

BERNARDES, B.; LUCIAN, R. (2015) Crowdfunding: A influência da co-criação e do sentimento de pertença na satisfação dos apoiadores luso-brasileiros. Revista Gestão Org., v. 13, Edição Especial. p. 360-369 ISSN 1679-1827 http://www.revista.ufpe.br/gestaoorg.

BRAMBILLA, F. R.; DAMACENA, C. (2012) Cocriação de valor no ensino superior privado: uma análise etnometodológica com alunos de administração de uma universidade do sul do Brasil. Administração: Ensino e Pesquisa, v. 13, n. 3, p. 455-490.

BRAMBILLA, F. R. (2010) Entendendo a lógica dominante do serviço em marketing: conceitos e premissas. XXXIV encontro da ANPAD. Rio de Janeiro/RJ - 25 a 29 de setembro de 2010.

BRAMBILLA, F. R. (2010) Abordagem etnometodológica acerca da co-criação de valor na graduação em Administração do ensino superior privado / Flávio Régio Brambilla; orientador Claudio Damacena. - São Leopoldo. Tese (Doutorado em Administração). Universidade do Vale do Rio dos Sinos.

CAMARINHA, D.; COSTA, B. K.; VIEIRA, S. F. A. (2013) Dinâmica da cocriação de valor no setor da saúde: um estudo de casos múltiplos no mercado paulista. PRETEXTO 2013 Belo Horizonte v. 14, n. 1, p. 88-105. ISSN 1517-672 x (Revista impressa) ISSN 19846983 (Revista online). 
CLAYSON, D. E. (2009) Student Evaluations of Teaching: Are They Related to What Students Leam? A Meta-Analysis and Review of the Literature. Journal of Marketing Education. v. 31, n. 1, p. 16-30.

CICCANTELLI, S.; MAGIDSON, J. (1993) Consumer Idealized Design: Involving Consumers in the Product Development Process. Journal of Product Innovation Management, v. 10, p. 341-347.

CHUNG, E.; McLARNEY, C. (2000) The Classroom as a Service Encounter: Suggestions for Value Creation. Journal of Management Education, v. 24, n. 4, p. 484-500.

DIETRICH, J. F.; BRASIL, V. S.; FRIO, R. S. (2013) O processo de cocriação de valor entre empresas e consumidores: uma análise comparativa de dois casos da indústria de bens e consumo. RAIMED - Revista de Administração IMED, v. 3, n. 3, p. 221-238 - ISSN 22377956.

D’AVILA, L. C.; DAMACENA, C.; GARRIDO, I. L. (2008) Valor de Marca na Nova Lógica de Serviços. In: Anais do XXXII EnANPAD. Rio de Janeiro: ANPAD.

DUKE, C. R. (2002) Learning Outcomes: Comparing Student Perceptions of Skill Level and Importance. Journal of Marketing Education. v. 24, n. 3, p. 203-217.

DONG, B.; EVANS, K. R.; ZOU, S. (2008) The Effects of Customer Participation in CoCreated Service Recovery. Journal of Academy of Marketing Science, v. 36, n. 1, p. 123-137.

EDVARDSSON, B.; TRONVOLL, B.; GRUBER, T. (2011) Expanding Understanding of Service Exchange and Value Co-Creation: A Social Construction Approach. Journal of the Academy of Marketing Science, v. 39, n. 2, p. 327-339.

FASSINGER, P. A. (1995) Understanding Classroom Interaction: Students' and Professors' Contributions to Students' Silence. Journal of Higher Education, v. 66, n. 1, p. 82-96.

FONTOURA B. B. F.; WITTMANN, M. L. (2016) Organizações e desenvolvimento: reflexões epistemológicas. Revista do CEPE. Santa Cruz do Sul, n. 43, p. 101-118.

GHEMAWAT, P. (2007) A estratégia e o cenário dos negócios: texto e casos. 2. ed. Porto Alegre: Bookman.

GRANITZ, N. A.; KOERNIG, S. K.; HARICH, K. R. (2009) Now It's Personal: Antecedents and Outcomes of Rapport between Business Faculty and their Students. Journal of Marketing Education, v. 31, n. 1, p. 52-65.

GRÖNROOS, C. (2011) A Service Perspective on Business Relationships: the Value Creation, Interaction and Marketing Interface. Industrial Marketing Management, v. 40, n. 2, p. 240-247.

GRÖNROOS, C.; RAVALD, A. (2011) Service as Business Logic: Implications for Value Creation and Marketing. Journal of Service Management, v. 22, n. 1, p. 5-22.

HOFSTATTER, C. R. (2010) Estudo dos efeitos da co-cocriação de valor no desempenho percebido, satisfação e lealdade / por Cássia Rebelo Hofstatter. - São Leopoldo.

HOLBROOK, M. (2002) (Ed.) Consumer value: a framework for analysis and research. Routledge, 2002.

HOMANS, G. C. (1977) As Pesquisas na Western Electric. In: BALCÃO, Y.; CORDEIRO, L. O Comportamento Humano na Empresa. 3.ed. Rio de Janeiro: FGV. 
KOTZÉ, T. G.; PLESSIS, P. F. (2003) Students as “Co-Producers” of Education: A Proposed Model of Student Socialization and Participation at Tertiary Institutions. Quality Assurance in Education, v. 11, n. 4, p. 186-201.

MALHOTRA, N. K. (2001) Pesquisa de marketing: uma orientação aplicada. 3. ed. Porto Alegre: Bookman.

MATIAS, A. P.; CIPRIANI, R.; SILVA, C. D.; GLAVAM, R. B.; MICHELS, E.; MICHELS, E. (2015) A cocriação de valor no ensino superior privado: um estudo de caso no curso de administração da faculdade Capivari - FUCAP. XV Colóquio Internacional de Gestão Financeira no Século XXI Mar del Plata - Argentina 2, 3 e 4 de dezembro de 2015.

MEUTER, M. L.; OSTROM, A. L.; ROUNDTREE, R. I.; BITNER, M. J. (2000) Self-srvice technologies: understanding customer satisfaction with technology-based service encounters. Journal of Marketing, v. 64, p. 50-64.

MEYER JÚNIOR, V.; MURPHY, J. P. (2003) Dinossauros, gazelas e tigres: novas abordagens da administração universitária, um diálogo Brasil e EUA. 2 ed. Florianópolis: Insular.

MORAES, R. O.; et al. (2013) Gestão Estratégica de Custos: Investigação da Produção Científica no Período de 2008 a 2012. In: Congresso Brasileiro De Custos, 20., Uberlândia. Anais.... São Leopoldo: Associação Brasileira de Custos.

NAMBISAN, S. (2002) Designing virtual customer environments for new product development. Academy of Management Review, v. 27, p. 392-413.

OLIVEIRA, S. C. M.; et al. (2013) Bibliometria em artigos de contabilidade aplicada ao setor público. In: CONGRESSO BRASILEIRO DE CUSTOS, 20., Uberlândia. Anais.... São Leopoldo: Associação Brasileira de Custos.

OLIVEIRA, T. M. V.; IKEDA, A. A. (2005) O conceito de valor para o cliente: definições e implicações gerenciais em marketing. Gestão Org., v. 3, n. 1.

PAYNE, A. F; STORBACK, K.; FROW, P. (2008) Manangin the co-creation of value. Journal of the Academy of Marketing Science, Greenvale, USA, v. 36, p. 83-96.

PAYNE, A. F.; STORBACKA, K.; FROW, P. (2007) Managing the co-creation of value. Journal of the Academy of Marketing Science, v. 36, n. 1, p. 83-96.

PRAHALAD, C. K.; RAMASWAMY, V. (2004a) Co - Creation Experiences: the Next Practice in Value Creation. Journal of Interactive Marketing, v. 18, n. 3, p. 5-14.

QIAN, B. (2006) Expectation, Service Quality, and Satisfaction in Higher Education: School of Management Strategic Marketing Group. MSc Theses (School of Management: Master of Science). Supervisor: Paul Baines. Cranfield University, p. 1-95, September.

RAY, S.; KIM, S. S.; MORRIS, J. G. (2012) Research Note-Online Users' Switching Costs: Their Nature and Formation. Information Systems Research, v. 23, n. 1, p. 197-213.

RAMASWAMY, V. (2009a) Leading The Transformation To Co-Creation Of Value. Strategy \& Leardship, Emerald Group Publishing Limited, v. 37, n. 2, p. 32-37.

RIBEIRO, H. C. M.; TAVARES, V. C. M.; COSTA, B. K. (2016) Cocriação de valor: uma bibliometria de 2000 a 2014. Revista Eletrônica de Estratégia \& Negócios, Florianópolis, v. 9, n. 1 . 
RICHINS, M. L. (1994) Value things. the public and private meanings of possessions. Journal of Consumer Research. December, Chicago, v. 21, n. 3, p. 504-521.

RIBEIRO, M. (1999) Universidade brasileira pós-moderna: democratização x competência. Manaus: Universidade do Amazonas.

ROMERO, D.; MOLINA, A. (2011) Collaborative networked organisations and customer communities: value co-creation and coinnovation in the networking era. Production Planning \& Control, v. 22, n. 56, 447-472.

SANTIAGO, M.; COUTINHO, O. (2013) Debate sobre o papel do espaço de ensino do design no contexto contemporâneo. Notas de aula. Escola do Design - Universidade do Estado de Minas Gerais.

SARACENI, S. (2015) Cocriação de valor no relacionamento empresa-cliente: um estudo exploratório / Sandra Saraceni. - São Paulo, 210 p.

SIERRA, J. (2009) Shared Responsibility and Student Learning Ensuring a Favorable Educational Experience. Journal of Marketing Education. v. XX, n. X.

SILVA, M. (2003) Educação na Cibercultura: O Desafio Comunicacional do Professor Presencial e Online. Revista FAEEBA, v. 12, n. 20, p. 261-271.

SLATER, S. F.; OLSON, E. M. (2000) Strategy Type and Performance: The Influence of Sales Force Management. Strategic Management Journal, v. 21, p. 813-829.

SRIVASTAVA, R. K.; SHERVANI, T. A.; FAHEY L. (1998) Market-Based Assets and Shareholder Value: A Framework for Analysis. Journal of Marketing, v. 62, p. 2-18.

VARGO, S. L.; MAGLIO, P. P.; AKAKA, M. A. (2008) On Value and Value Co-Creation: A Service Systems and Service Logic Perspective. European Management Journal, v. 26, n. 1, p. 145-152.

VARGO, S. L. (2008) Customer Integration and Value Creation: Paradigmatic Traps and perspectives. Journal of Service Research, v. 11, n. 2, p. 211-215.

VARGO, S. L.; MORGAN, F. W. (2005) Services in Society and Academic Thought: An Historical Analysis. Journal of Macromarketing, v. 25, n. 1, p. $42-53$.

VARGO, S. L.; LUSCH, R. F.; MORGAN, F. W. (2006) Historical Perspectives on Service-Dominant Logic. In: LUSCH, R. F.; VARGO, S. L. (Editors). The ServiceDominant Logic of Marketing: Dialog, Debate, and Directions. New York: M. E. Sharpe, p. 29-42.

VARGO, S. L.; LUSCH, R. F. (2004) Evolving to a New Dominant Logic for Marketing. Journal of Marketing, v. 68, p. 1-17.

WITELL, L.; KRISTENSSON, P.; GUSTAFSSON, A.; LÖFGREN, M. (2011) Idea generation: customer co-creation versus traditional market research techniques. Journal of Service Management, v. 22, n. 2, p. 140-159.

WOODRUFF, R. B.; FLINT, D. J. (2006) Marketing's service-dominant logic and customer value. The service-dominant logic of marketing: Dialog, debate, and directions, $\mathrm{p}$. 183-195.

YOUNG, M. R. (2005) The Motivational Effects of the Classroom Environment in Facilitating Self-Regulated Learning. Journal of Marketing Education, v. 27, n. 1, p. 25-40. 